\title{
The assessment of the technical condition of the bearing seals of the rotor shaft in a turbine helicopter engine based on the PM content in the exhaust gases
}

\author{
The paper presents the method of measurement of the particulate matter in the exhaust gases of a Rolls-Royce Allison \\ 250-C20B turbine engine in the aspect of the assessment of the technical condition of the bearing seals of the rotor shaft. \\ The tests were carried out on 4 engines using a Horiba TEOM 1105 PM analyzer fitted with a mini dilution tunnel-Micro \\ Diluter 6100. The paper also presents the method of determining of the engine technical condition index (bearing seals) \\ developed by the authors based on the data obtained from the measurements. The reliability of the obtained results has \\ also been subjected to evaluation.
}

Key words: turbine engine, exhaust emissions, particulate matter (PM), technical condition index

\section{Ocena stanu technicznego uszczelnień układu łożyskowania wałów wirnika turbinowego silnika śmigłowcowego na podstawie zawartości cząstek stałych w gazach wylotowych}

$W$ artykule przedstawiono sposób pomiaru emisji cząstek stałych $w$ gazach wylotowych silnika turbinowego RollsRoyce Allison 250-C20B w aspekcie oceny stanu technicznego uszczelnień układu tożyskowania wałów wirnika. Badania przeprowadzono na czterech silnikach, przy użyciu analizatora czastek statych Horiba TEOM 1105 wyposażonego w minitunel rozcieńczający Micro Diluter 6100. Zaprezentowano opracowana przez autorów metodę wyznaczania wskaźnika stanu technicznego silnika (uszczelnień łożysk), opierając się na danych uzyskanych z pomiarów. Poddano również ocenie wiarygodność uzyskanych wyników.

Słowa kluczowe: silnik turbospalinowy, emisja gazów wylotowych, czastki state (PM), wskaźnik stanu technicznego

\section{Introduction}

The content of PM in the exhaust gases of a turbine engine heavily depends on the amount of oil getting through the seals of the rotor shafts to the flow channel and the operation of the automatic fuel dosage system (proper fuel supply for each engine operating range). The oil is burned as a result of the contact with the hot elements of the channel and the generated particles are evacuated from the engine together with the exhaust gases. To some extent this is a natural phenomenon and its intensity can be controlled by a systematic checks of the oil consumption assuming that the external oil system is tight.

If the oil consumption exceeds the admissible value as a result of combustion in the flow channel of the engine it may result in a reduced engine lubrication and cooling, the results of which could be the damage of the bearing whose seal was destroyed and hot carbon sediments may deposit on the hot elements of the flow channel. An external symptom of this type of leakage is a white smoke getting out of the exhaust pipes after the engine is stopped. In such a situation we should expect a significant increase in the emission of PM in the exhaust gases. The recording of this content during the engine trials at different operating ranges may enable an identification of the engine operating range and conditions directly connected to the occurrence of the increased PM emission, and, at the same time facilitate the diagnostic reasoning and identify the problem of the leakage in the shaft support long before the white smoke appears.

\section{Wstęp}

Zawartość cząstek stałych w gazach wylotowych silnika turbinowego zależy między innymi od ilości oleju przedostającego się poprzez uszczelnienia wałów wirnika do kanału przepływowego oraz od działania układu automatycznej regulacji podającego do komory spalania właściwą dla każdego zakresu pracy silnika ilość paliwa. Olej ulega spaleniu w wyniku kontaktu z gorącymi elementami kanału, a wytworzone cząstki stałe usuwane są z silnika razem z gazami wylotowymi. Jest to zjawisko do pewnego stopnia naturalne, a jego intensywność może być kontrolowana przez systematyczny pomiar zużycia oleju, przy założeniu, że zewnętrzna instalacja olejowa jest szczelna.

Jeżeli w wyniku spalania oleju w kanale przepływowym silnika zużycie oleju przekroczy wartość dopuszczalną, to skutkiem tego może być pogorszenie smarowania i chłodzenia łożyska, którego uszczelnienie zostało uszkodzone i osadzanie się nagaru na gorących elementach kanału przepływowego. Zewnętrznym objawem pojawienia się tego rodzaju nieszczelności jest wydostawanie się białego dymu z rur wylotowych po wyłączeniu silnika. W tej sytuacji należy spodziewać się wyraźnego wzrostu zawartości cząstek stałych w gazach wylotowych. Rejestracja tej zawartości w czasie próby silnika pracującego na różnych zakresach może umożliwić identyfikację zakresu i warunków pracy silnika jednoznacznie związanych z pojawianiem się wzrostu zawartości cząstek stałych, a tym samym ułatwić wnioskowanie diagnostyczne i dostrzec problem szczelności podpór znacznie wcześniej przed pokazaniem się dymu. 
The measurement of the PM content in the exhaust gases of a turbine engine may turn out useful when verifying the operation of the bearing seals after reassembling the engine elements together.

The paper presents the methodology of measurement of the particulate matter in the engine exhaust gases as well as the methodology of determining of the engine technical condition index (based on the data obtained from the measurements) developed by the authors of this paper.

The threshold (reference) value of the functional diagnostic signal CS(t) was determined and then the principle of calculation of the excess values in the time domain $t$ (short term) was presented along with the way of determining of the engine technical condition index in the time domain $t$ and time of operation (long term) $\Theta$.

\section{Object of investigations}

The object of the investigation was a turbine Rolls-Royce Allison 250-C20B engine (Tab. 1). The type series Allison 250 are fitted with a centrifugal compressor and a free drive turbine that transfers the torque to the external power takeoff (Fig.1). This design is typical of helicopter applications. The measurements were conducted on four engines of this type fitted in two helicopters PZL Kania (Fig. 2).
Pomiar zawartości cząstek stałych w gazach wylotowych silnika turbinowego może być również przydatny do weryfikacji działania uszczelnień łożysk po wykonaniu montażu elementów wirnika.

W opracowaniu przedstawiono sposób pomiaru emisji cząstek stałych w gazach wylotowych silnika turbinowego oraz opracowaną przez autorów tego artykułu metodykę wyznaczania wskaźnika stanu technicznego silnika w oparciu o dane uzyskane $\mathrm{z}$ powyższych pomiarów.

Wyznaczono wartość odniesienia (progową) funkcjonalnego sygnału diagnostycznego $\mathrm{CS}(\mathrm{t})$, a następnie przedstawiono zasadę obliczania przekroczeń tej wartości w dziedzinie czasu krótkiego t oraz sposób wyznaczania wskaźnika stanu technicznego w dziedzinie czasu t i czasu eksploatacji (długiego) $\Theta$.

\section{Obiekt badań}

Jako obiekt badań wybrano turbinowy silnik Rolls-Royce Allison 250-C20B (tab. 1). Silniki typoszeregu Allison 250 posiadają sprężarkę osiowo-odśrodkową oraz swobodną turbinę napędową, która przekazuje moment na

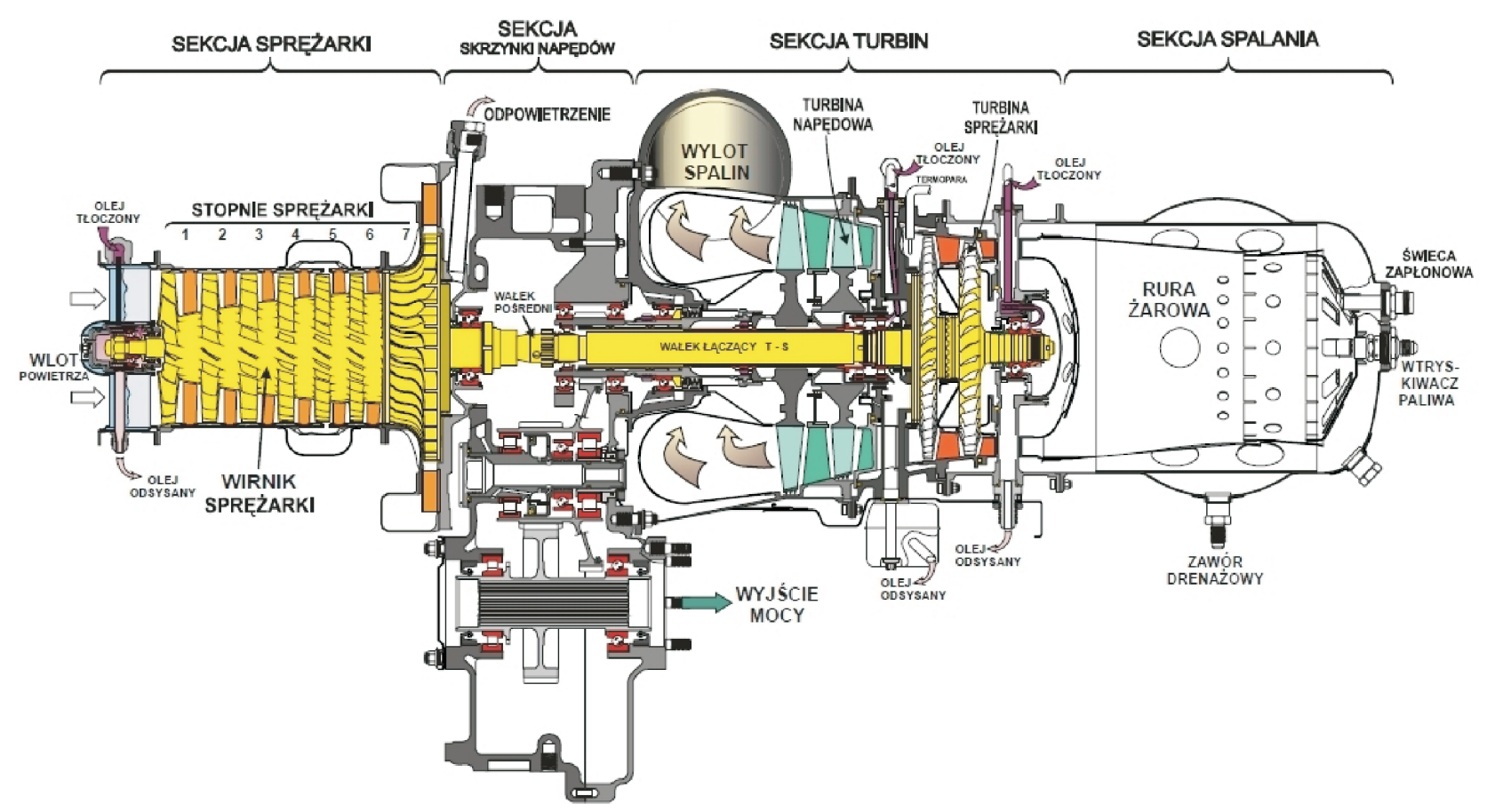

Fig. 1. Diagram of the Rolls-Royce Allison 250-C20B turbine engine [1] Rys. 1. Schemat silnika turbinowego Rolls-Royce Allison 250-C20B [1] 


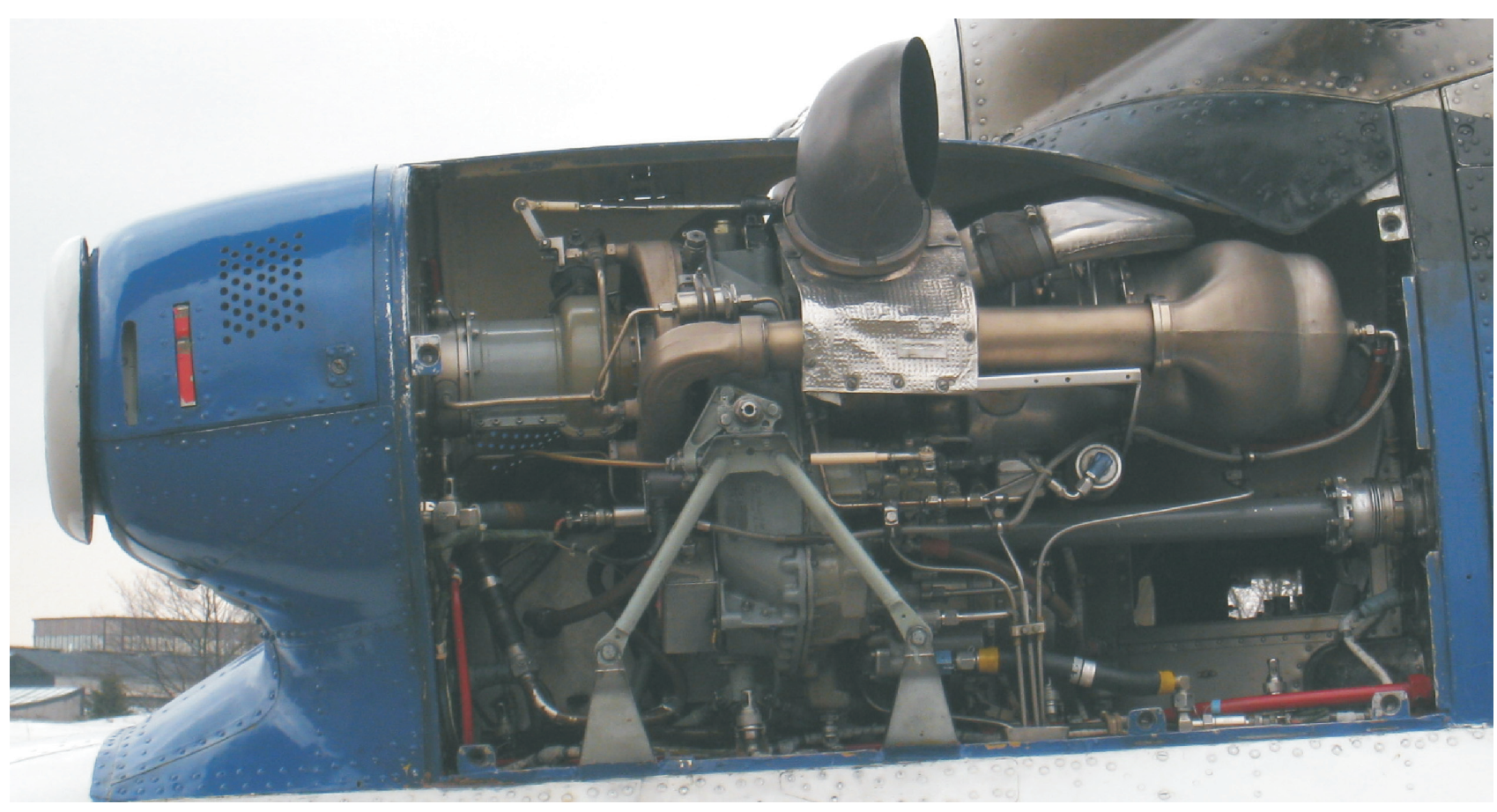

Fig. 2. Rolls-Royce Allison 250-C20B turbine engine mounted in the PZL Kania helicopter Rys. 2. Silnik turbinowy Rolls-Royce Allison 250-C20B zabudowany w śmigłowcu PZL Kania

\section{Research equipment}

In the tests Horiba TEOM 1105 measurement system was applied (Fig. 3) composed of oscillating micro balance TEOM and the exhaust dilution module Micro Diluter 6100 connected with the mini dilution tunnel (Fig. 4). This device was designed for the measurement of the particulate

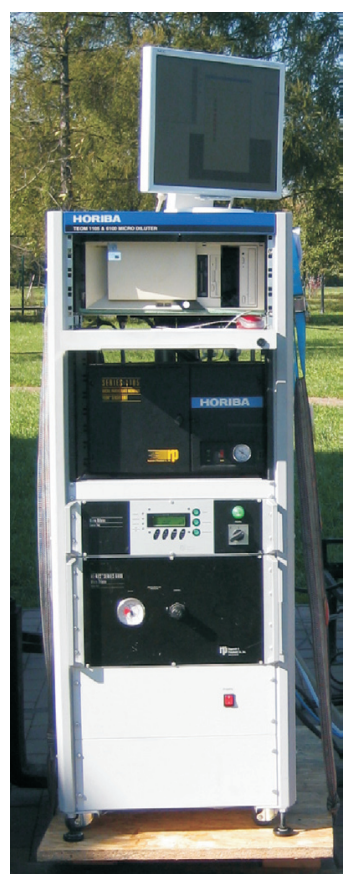

Fig. 3. Measuring system Horiba TEOM 1105

Rys. 3. System pomiarowy Horiba TEOM 1105 wyjściowy wał odbioru mocy (rys.1). Jest to rozwiązanie konstrukcyjne typowe dla zastosowań śmigłowcowych. Pomiary zostały przeprowadzone na czterech silnikach tego typu, stanowiących źródło napędu dwóch śmigłowców PZL Kania (rys. 2).

\section{Aparatura badawcza}

W badaniach zastosowano system pomiarowy Horiba TEOM 1105 (rys. 3), który składa się z mikrowagi oscylacyjnej TEOM oraz modułu rozcieńczania spalin Micro Diluter 6100, połączonego z minitunelem rozcieńczającym (rys. 4). Jest to urządzenie służące w założeniu do pomiaru emisji cząstek stałych w spalinach tłokowych silników z zapłonem samoczynnym. Cechy funkcjonalne analizatora

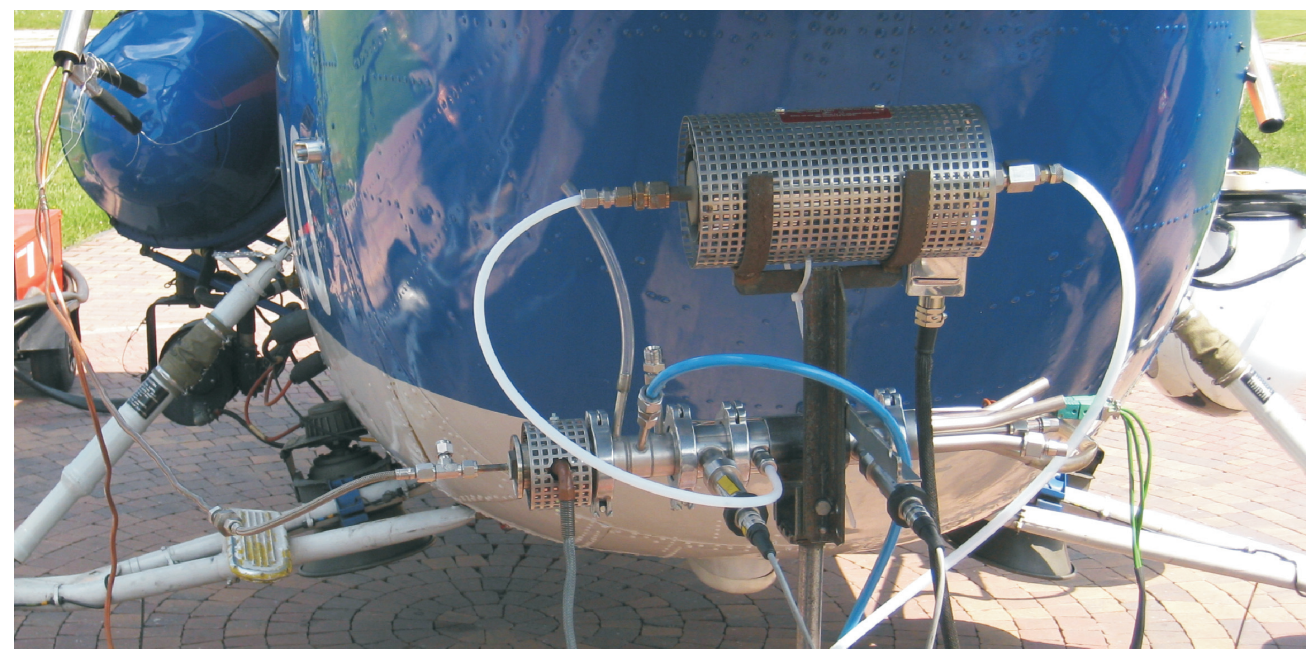

Fig. 4. Mini dilution tunnel on the test stand

Rys. 4. Minitunel rozcieńczający na stanowisku pomiarowym 


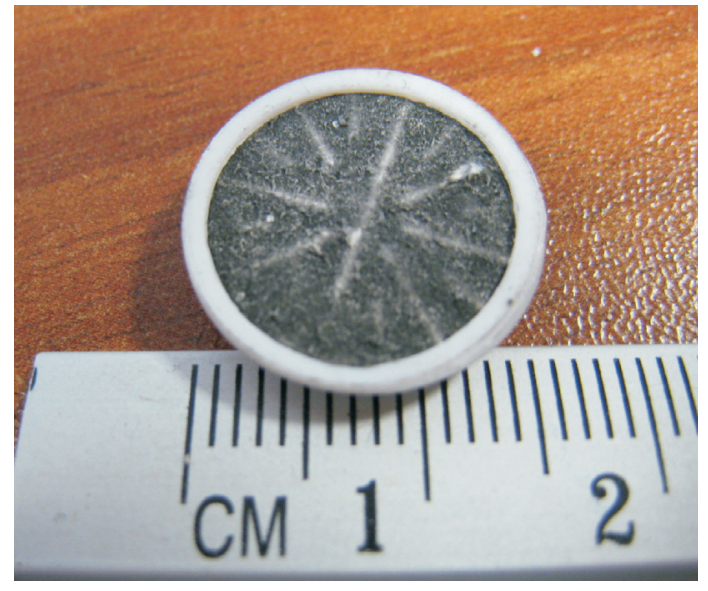

Fig. 5. Approximate dimensions of the TEOM filter; visible layer of the deposited particle matter Rys. 5. Orientacyjne wymiary filtra TEOM; widoczna warstwa osadzonych czastek statych

of this measurement system to this type of engine has been presented in work [6].

TEOM (Tapered Element Oscillating Microbalance) determined (based on the gravimetric method) the mass of the particulate matter in the flowing stream of exhaust gases. The determined volumetric constant exhaust volume of the diluted exhaust gases from the combustion engine flows through a special filter covered with PTFE (Fig. 5). The mass of the filter is measured on a continuous basis and is recorded by the measurement system. A detailed description of the device can be found in $[2,4,6]$.

\section{Methodology of measurement of the PM in the exhaust gases of a turbine engine}

Upon fitting of the exhaust gas probe the engine was started and an engine load was applied according to a procedure generally accepted in aviation $[3,5,6]$. The engine load was applied in the following stages: I - automatic engine start-up, engine reaches low range engine speed, II - low range (MG), III - intermediate range - until the flight range is reached (LOT), IV - flight range (LOT), V - back to low range, VI - low range (MG), VII - rev down of the turbo compressor.

During the whole engine trial the data from the TEOM were recorded (program - Fig. 6).

\section{The results of the PM emission tests}

The recorded values of the PM content in the exhaust gases of the Rolls-Royce Allison 250-C20B engines served as a source for the graph data presented in Figures 7 and 8 .

\section{The PM content in the exhaust gases of a turbine engine as a functional diagnostic signal CS(t)}

The exhaust sample taken from the exhaust system of the engine flows through the TEOM analyzer depositing the $\mathrm{PM}$, which results in the growth of its mass. This mass is measured at constant intervals $\Delta \mathrm{t}=0.1574 \mathrm{~s}$ and the results zadecydowały jednak o zastosowaniu go do pomiarów emisji cząstek stałych również w spalinach silnika turbinowego. Udaną adaptację systemu pomiarowego do tego typu silnika przedstawiono $\mathrm{w}$ artykule [6].

Mikrowaga oscylacyjna TEOM (Tapered Element Oscillating Microbalance) wyznacza na zasadzie grawimetrycznej masę cząstek stałych w przepływającym strumieniu gazów. Ustalony stały wydatek objętościowy rozcieńczonych gazów wylotowych z silnika spalinowego przepływa przez specjalny filtr wykonany z włókien szklanych pokrytych teflonem (rys. 5). Masa filtra jest mierzona w sposób ciągły i rejestrowana przez system pomiarowy. Szczegółowy opis urządzenia zamieszczono m.in. w publikacjach $[2,4,6]$.

\section{Metodyka pomiaru emisji cząstek stałych w gazach wylotowych silnika turbinowego}

Po zamocowaniu sondy do poboru próbki gazów wylotowych, uruchomiono badany silnik i obciążono go według przyjętej powszechnie w lotnictwie procedury $[3,5,6]$, obejmującej następujące etapy: I - automatyczne uruchomienie silnika, osiągnięcie prędkości obrotowej małego gazu, II - zakres małego gazu (MG), III - zakres przejściowy - do osiągnięcia zakresu LOT, IV - zakres LOT, V - przejście na zakres małego gazu, VI - zakres małego gazu (MG), VII - wybieg wirnika turbosprężarki.

Podczas całej próby silnika (program próby - rys. 6) prowadzono rejestrację danych $\mathrm{z}$ analizatora TEOM.

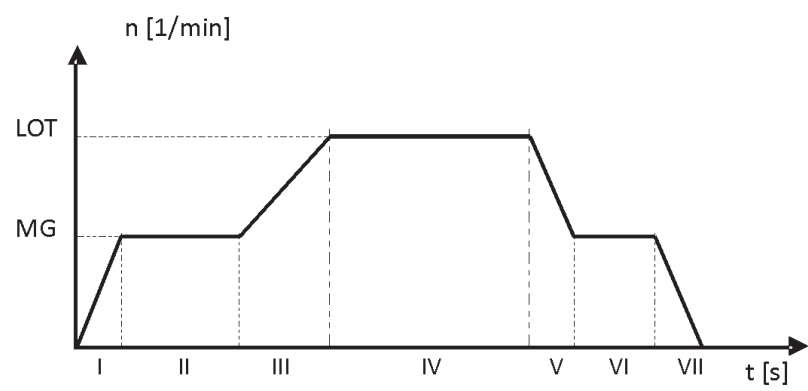

Fig. 6. Program of the RR Allison 250 engine test: MG - low range, LOT - flight range

Rys. 6. Program próby silnika RR Allison 250: $M G$-zakres małego gazu, LOT-zakres LOT

\section{Wyniki pomiaru emisji cząstek stałych}

Zarejestrowane wartości emisji cząstek stałych w gazach wylotowych silników Rolls-Royce Allison 250-C20B posłużyły do wykonania wykresów przedstawionych przykładowo na rysunkach 7 i 8.

\section{Zawartość cząstek stałych w gazach wylotowych silnika turbinowego jako funkcjonalny sygnal diagnostyczny CS(t)}

Próbka spalin (gazów wylotowych) pobierana z układu wylotowego silnika przepływa przez filtr analizatora TEOM, osadzając na nim cząstki stałe, co powoduje wzrost jego 


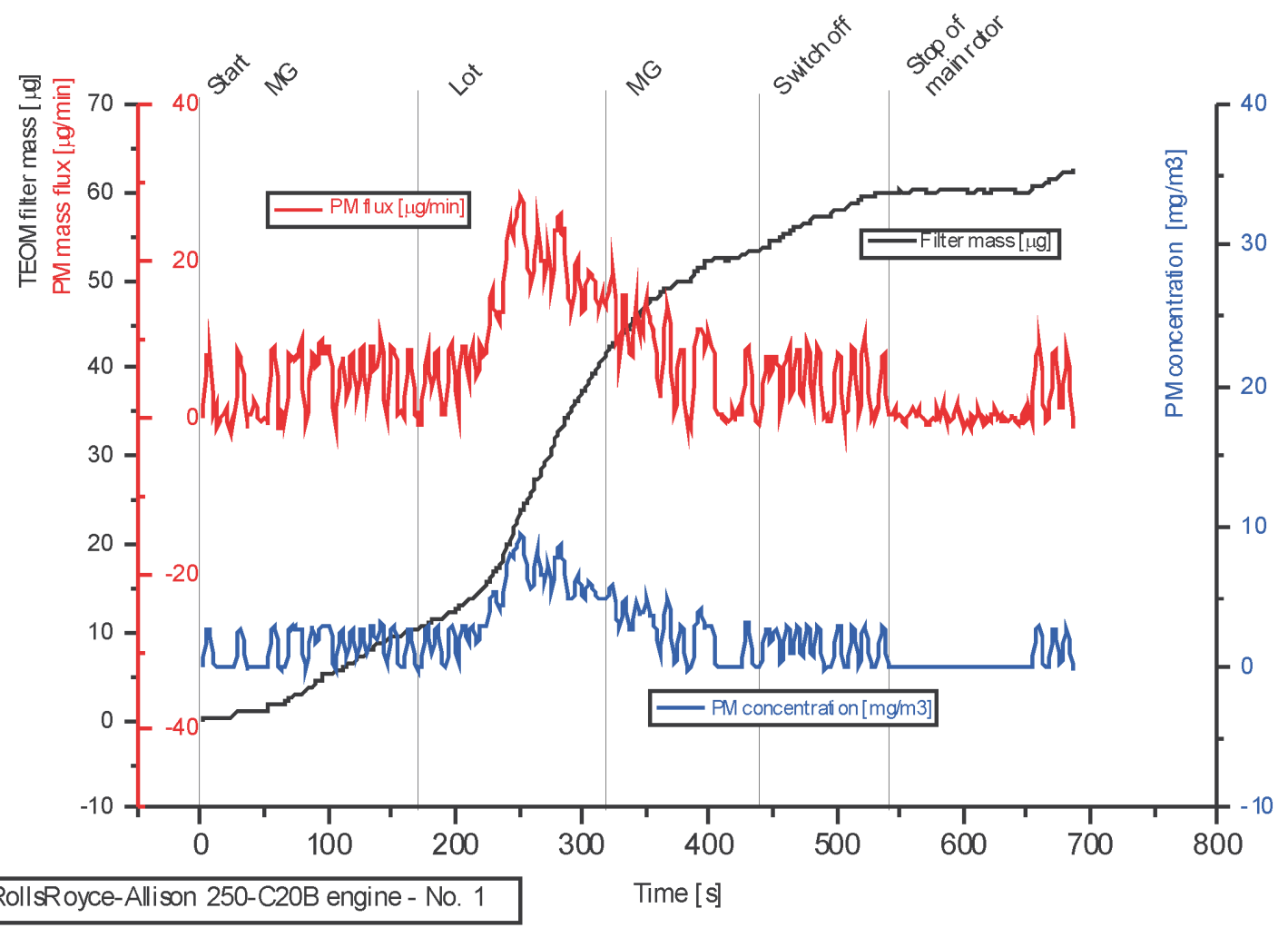

Fig. 7. Example of the record of particle matter concentration in the exhaust gases of Rolls-Royce Allison 250-C20B engine No. 1 - first test Rys. 7. Przykładowy zapis stężenia cząstek stalych w gazach wylotowych silnika Rolls-Royce Allison 250-C20B nr 1 - pierwsza próba

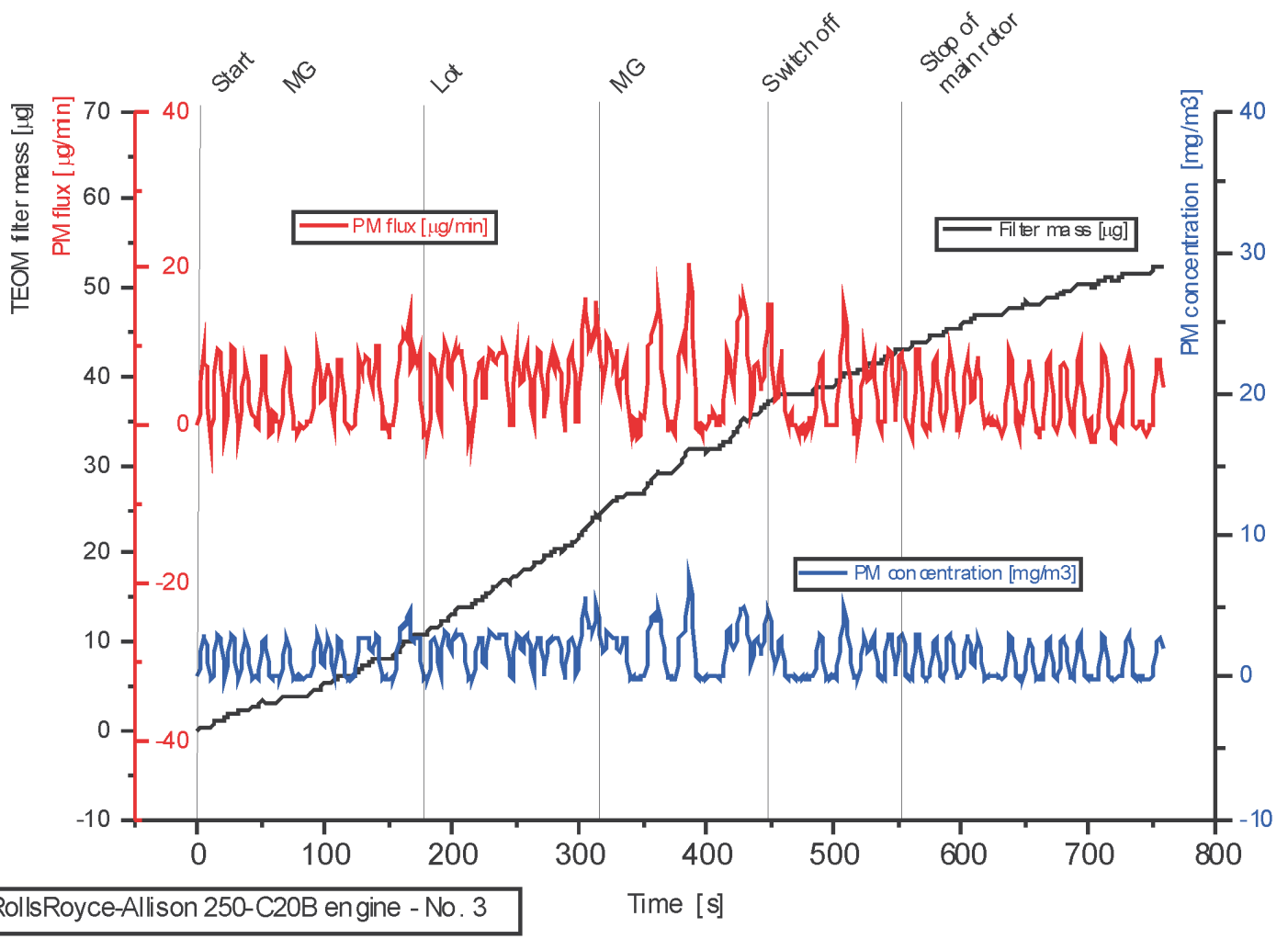

Fig. 8. Example of the record of particulate matter concentration in the exhaust gases of Rolls-Royce Allison 250-C20B engine No. 3 - first test Rys. 8. Przykładowy zapis stężenia cząstek stałych w gazach wylotowych silnika Rolls-Royce Allison 250-C20B nr 3-pierwsza próba 
are recorded and shown in the form of graphs CS(t) (where $\mathrm{t}=\mathrm{i} \cdot \Delta \mathrm{t})$ and numbers.

Two properties of this signal result from the above:

- because each time we measure the total filter mass, function $\mathrm{CS}(\mathrm{t})$ is nondecreasing;

- function $\operatorname{CS}(\mathrm{t})$ is the output signal of the integrating element - it remembers the values of this signal throughout the course of the recording.

Functional diagnostic signal $\mathrm{CS}(\mathrm{t})$ can be defined as follows:

$$
\operatorname{CS}(\mathrm{t})=\sum_{\mathrm{i}=1}^{\mathrm{n}} \Delta \mathrm{CS}(\mathrm{i} \cdot \Delta \mathrm{t})
$$

where: $\mathrm{n} \cdot \Delta \mathrm{t}=\operatorname{tr}$ - time of recording.

It is noteworthy that in the case of this signal we have a non-typical situation: the results of the diagnostic measurement is a characteristic presenting the course in a given time window $(0, \mathrm{tr})$ of a given physical quantity not, as it usually takes place, a numerical value of a diagnostic signal representing the technical condition at the moment of measurement.

\subsection{The threshold and maximum admissible values of the functional diagnostic signal}

The threshold (reference) value of the functional diagnostic signal can be defined as follows: it is the highest value of the functional diagnostic signal generated by an operative technical object with external interactions not exceeding the maximum admissible values.

If the value of the functional diagnostic signal exceeds the threshold value it means that a permanent or momentary cause appeared that modified the operation of an object resulting from a deterioration of the technical condition or an adverse impact of the surroundings. After eliminating of the cause of the damage or when the said adverse impact seizes the value of the signal may reduce below the threshold value.

The maximum admissible value of the functional diagnostic signal is a boundary value not to be exceeded in the whole life cycle of the technical object. The obtainment of the maximum admissible value results in an immediate withdrawal of the object from operation until the reasons are detected and eliminated.

In order to determine the threshold value we need to determine the values of the increments of the PM content in the subsequent measurement intervals $\Delta \mathrm{t}-$ we need to determine the course of $\Delta \mathrm{CS}(\Delta \mathrm{t})$ :

$$
\Delta \operatorname{CS}(\Delta \mathrm{t})=\operatorname{CS}(\mathrm{i} \cdot \Delta \mathrm{t})-\operatorname{CS}[(\mathrm{i}-1) \Delta \mathrm{t}]
$$

The recording time usually amounts to several seconds. We have a set of values of several hundred of $\Delta \operatorname{CS}(\Delta t)$ increments . If, in the diagnostic research we use an operative engine and the tests are carried out under conditions that ensure that the maximum admissible value of the external interactions is not exceeded then the threshold value of the signal $\Delta \mathrm{CS}(\Delta \mathrm{t})$ is obtained as follows: masy. Masa ta mierzona jest w stałych odstępach czasu $\Delta \mathrm{t}=0,1574 \mathrm{~s}$, a wyniki pomiarów są rejestrowane i przedstawiane w postaci wykresu CS $(\mathrm{t})($ gdzie $\mathrm{t}=\mathrm{i} \cdot \Delta \mathrm{t}) \mathrm{i}$ w postaci liczbowej.

Wynikają stąd następujące właściwości tego sygnału: - ponieważ za każdym razem mierzona jest całkowita masa filtra, funkcja CS(t) jest niemalejąca;

- funkcja CS(t) jest sygnałem wyjściowym elementu całkującego - ,pamięta” zatem wartości tego sygnału w ciągu całego przebiegu rejestracji;

- funkcjonalny sygnał diagnostyczny CS(t) można zdefiniować jako wzór (1), gdzie: $\mathrm{n} \cdot \Delta \mathrm{t}=\mathrm{tr}$ - czas rejestracji.

Należy zauważyć, że w przypadku tego sygnału mamy do czynienia z nietypową sytuacją: wynikiem pomiaru diagnostycznego jest charakterystyka przedstawiająca przebieg w określonym przedziale czasu $(0, \operatorname{tr})$ pewnej wielkości fizycznej, a nie jak to jest zazwyczaj, konkretna wartość liczbowa sygnału diagnostycznego, będąca obrazem stanu technicznego w chwili pomiaru.

\subsection{Wartość progowa i dopuszczalna funkcjonalnego sygnału diagnostycznego}

Wartość progową (odniesienia) funkcjonalnego sygnału diagnostycznego można zdefiniować następująco: jest to największa wartość funkcjonalnego sygnału diagnostycznego generowanego przez sprawny obiekt techniczny przy oddziaływaniach zewnętrznych nieprzekraczających wartości dopuszczalnych.

Jeżeli wartość funkcjonalnego sygnału diagnostycznego przekracza wartość progową, oznacza to, że pojawiła się stała lub chwilowa przyczyna powodująca zmianę działania obiektu, wynikająca z degradacji stanu technicznego lub niekorzystnego oddziaływania otoczenia. Po usunięciu przyczyny uszkodzenia lub ustaniu oddziaływania wartość sygnału może zmniejszyć się poniżej wartości progowej.

Wartość dopuszczalna funkcjonalnego sygnału diagnostycznego jest wartością graniczną, nieprzekraczalną w całym okresie eksploatacji obiektu technicznego. Osiągnięcie wartości dopuszczalnej powoduje natychmiastowe przerwania użytkowania do czasu ustalenia i usunięcia przyczyny, która ten wzrost spowodowała.

W celu wyznaczenia wartości progowej należy wyznaczyć wartości przyrostów zawartości cząstek stałych w kolejnych okresach pomiarowych $\Delta \mathrm{t}$, czyli wyznaczyć przebieg $\Delta \mathrm{CS}(\Delta \mathrm{t})$ - wzór (2).

Czas rejestracji wynosi zazwyczaj kilkadziesiąt sekund. Dysponujemy więc zbiorem wartości kilkuset przyrostów $\Delta \mathrm{CS}(\Delta \mathrm{t})$. Jeżeli w badaniach diagnostycznych korzysta się $\mathrm{z}$ silnika sprawnego technicznie i badania przeprowadzane są w warunkach zapewniających nieprzekraczanie wartości dopuszczalnych oddziaływań zewnętrznych, to wartość progową sygnału $\Delta \mathrm{CS}(\Delta \mathrm{t})$ wyznacza się według wzoru (3), gdzie: $\mu_{\Delta \mathrm{CS}}$, $\sigma_{\Delta \mathrm{CS}}$ - parametry rozkładu normalnego wartości przyrostów sygnału $\Delta \mathrm{CS}(\Delta \mathrm{t})$ wyznaczone dla każdego badanego silnika.

Dla każdego z czterech badanych silników RR Allison 250-C20B wykonano po dwie rejestracje sygnału CS(t). Przyjęto następujące oznaczenia: 1 - silnik nr 836434, 2 - silnik nr 836446, 3 - silnik nr 836788, 4 - silnik nr 836791. 


$$
\Delta \mathrm{CS}_{\mathrm{pr}}=\mu_{\Delta \mathrm{CS}}+3 \sigma_{\Delta \mathrm{CS}}
$$

where: $\mu_{\triangle C S}, \sigma_{\triangle C S}-$ the parameters of normal distribution of the values of increments of signal $\Delta \mathrm{CS}(\Delta \mathrm{t})$ determined for each tested engine.

For each of the four tested RR Allison 250-C20B engines two CS(t) signal recording have been performed. The following notations have been adopted: 1 - engine number 836434,2 - engine number 836446, 3 - engine number 836788, 4 - engine number 836791.

The PM content in the exhaust is also a function of oil consumption. The admissible oil consumption for this type of engines is $0.2 \mathrm{l} / \mathrm{h}$. Since none of the tested engines exceeded this oil consumption limit and the actual oil consumption was not recorded, the authors assumed that the oil consumption was half of that admissible $(0.1 \mathrm{l} / \mathrm{h})$.

If the admissible value of the PM content is determined as the PM content in the exhaust gases at an admissible oil consumption then the admissible value of $\Delta \mathrm{CS}_{\mathrm{dop}}$ is twice as high as the threshold value:

$$
\Delta \mathrm{CS}_{\mathrm{dop}}=2 \cdot \Delta \mathrm{CS}_{\mathrm{pr}}
$$

The aim of the conducted experiment was to ascertain the methodology of the diagnostic tests and diagnostic reasoning not testing of the technical condition of the said engines - it
Zawartość cząstek stałych w gazach wylotowych jest funkcją między innymi zużycia oleju. Dopuszczalne zużycie oleju dla tego typu silników wynosi 0,2 l/h. Ponieważ żaden $\mathrm{z}$ badanych silników nie wykazywał tendencji do przekroczenia zużycia dopuszczalnego, a rzeczywiste zużycie nie było rejestrowane, przyjęto, że stanowi ono połowę zużycia dopuszczalnego $(0,1 \mathrm{l} / \mathrm{h})$.

Jeżeli wartość dopuszczalną zawartości cząstek stałych określimy jako ich zawartość w gazach wylotowych przy dopuszczalnym zużyciu oleju, to przy powyższym założeniu wartość dopuszczalna $\Delta \mathrm{CS}_{\text {dop }}$ jest dwukrotnie większa od wartości progowej (4).

Celem przeprowadzonego eksperymentu było ustalenie metodyki badań diagnostycznych i wnioskowania diagnostycznego, a nie badanie stanu technicznego wymienionych silników - nie było to możliwe w tak krótkim czasie ich pracy i po wykonaniu dwóch rejestracji dla każdego egzemplarza. $Z$ tego też względu powyższe założenie wielkości rzeczywistego zużycia oleju nie ma wpływu na wnioski wynikające z wyników badań.

Na rysunkach $9-12$ przedstawiono przebiegi funkcjonalnych sygnałów diagnostycznych $\Delta \mathrm{CS}(\Delta \mathrm{t})$ zarejestrowanych dla śmigłowcowych silników turbinowych Rolls-Royce Allison 250-C20B.
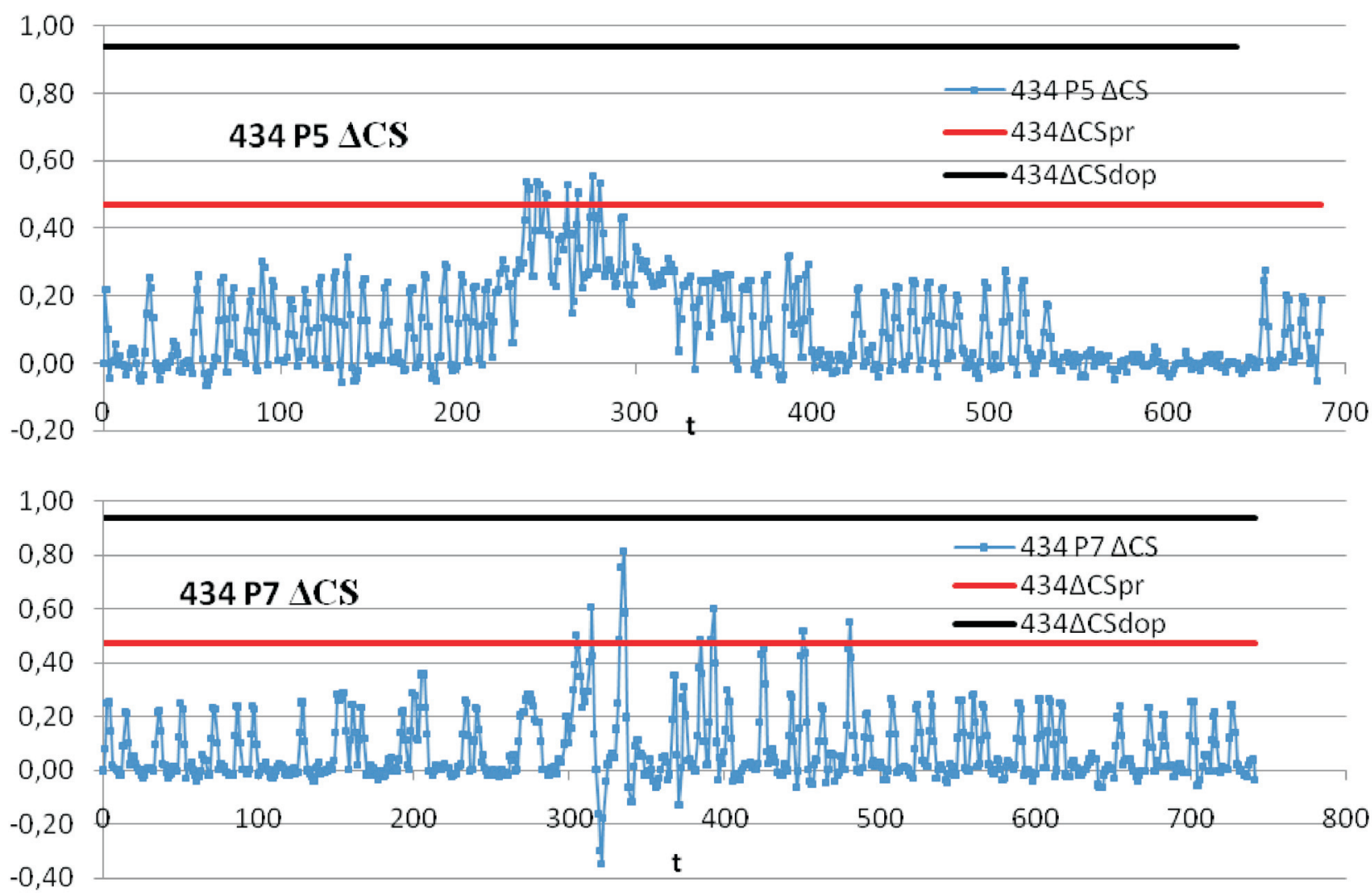

Fig. 9. Course of the functional diagnostic signal $\Delta \mathrm{CS}(\Delta \mathrm{t})-\mathrm{RR}$ Allison 250-C20B engine No. 1 - first and second record. Notations: $\Delta \mathrm{CS}_{\mathrm{pr}}$ - threshold value of the diagnostic signal, $\Delta \mathrm{CS}_{\mathrm{dop}}$ - maximum admissible value of the diagnostic signal

Rys. 9. Przebieg funkcjonalnego sygnatu diagnostycznego $\triangle C S(\Delta t)$ - silnik RR Allison 250-C20B nr 1 - pierwsza i druga rejestracja Oznaczenia: $\triangle C S_{p r}$ - wartość progowa sygnału diagnostycznego, $\Delta C S_{d o p}$ - wartość dopuszczalna sygnału diagnostycznego 

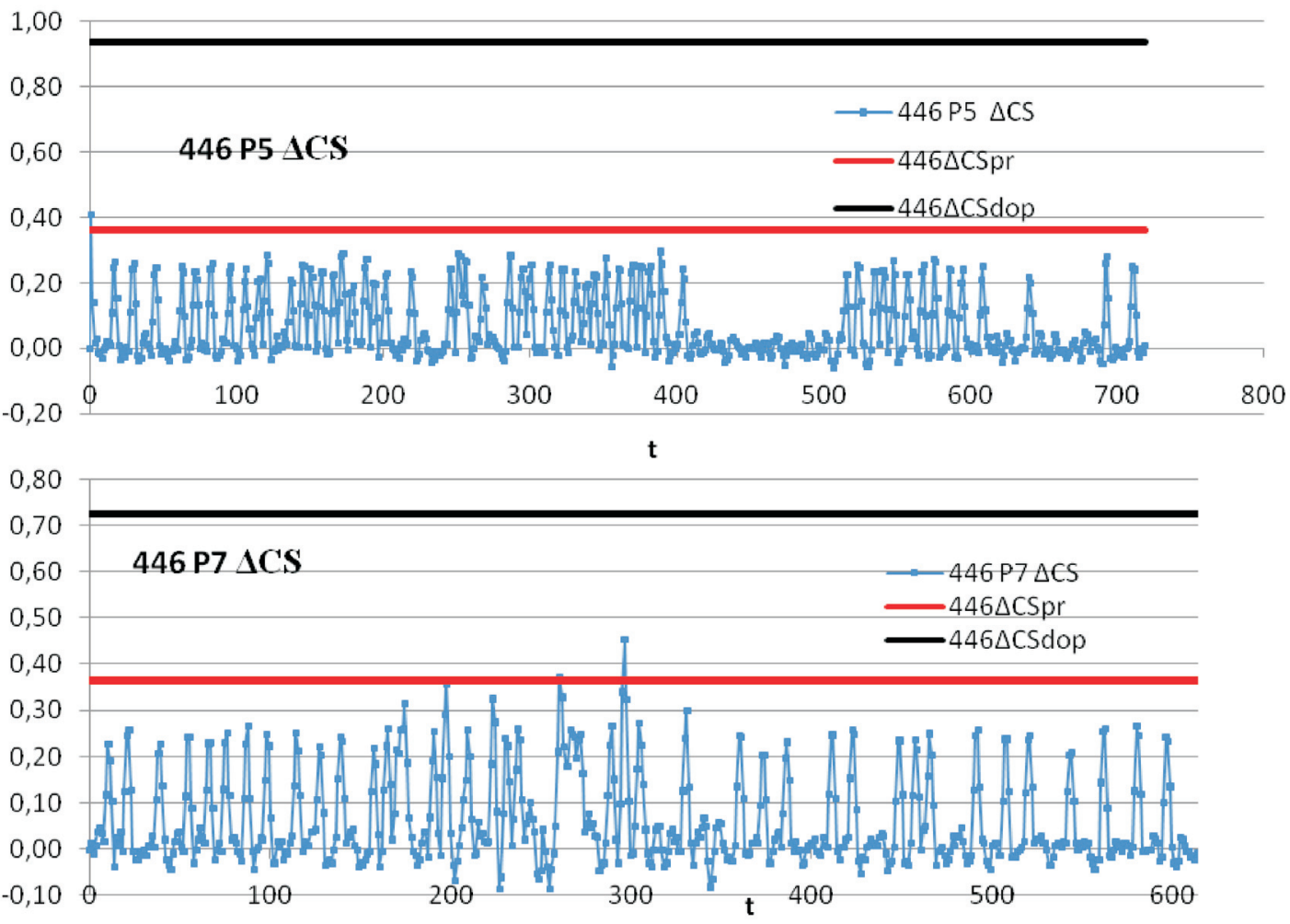

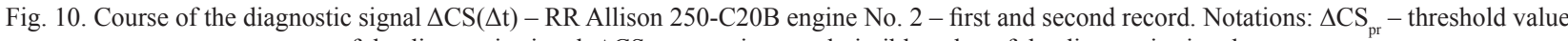
of the diagnostic signal, $\triangle \mathrm{CS}_{\mathrm{dop}}-$ maximum admissible value of the diagnostic signal

Rys. 10. Przebieg funkcjonalnego sygnalu diagnostycznego $\triangle C S(\Delta t)$ - silnik RR Allison 250-C20B nr 2 - pierwsza i druga rejestracja. Oznaczenia: $\Delta C S_{p r}$ - wartość progowa sygnatu diagnostycznego, $\Delta C S_{\text {dop }}$ - wartość dopuszczalna sygnału diagnostycznego
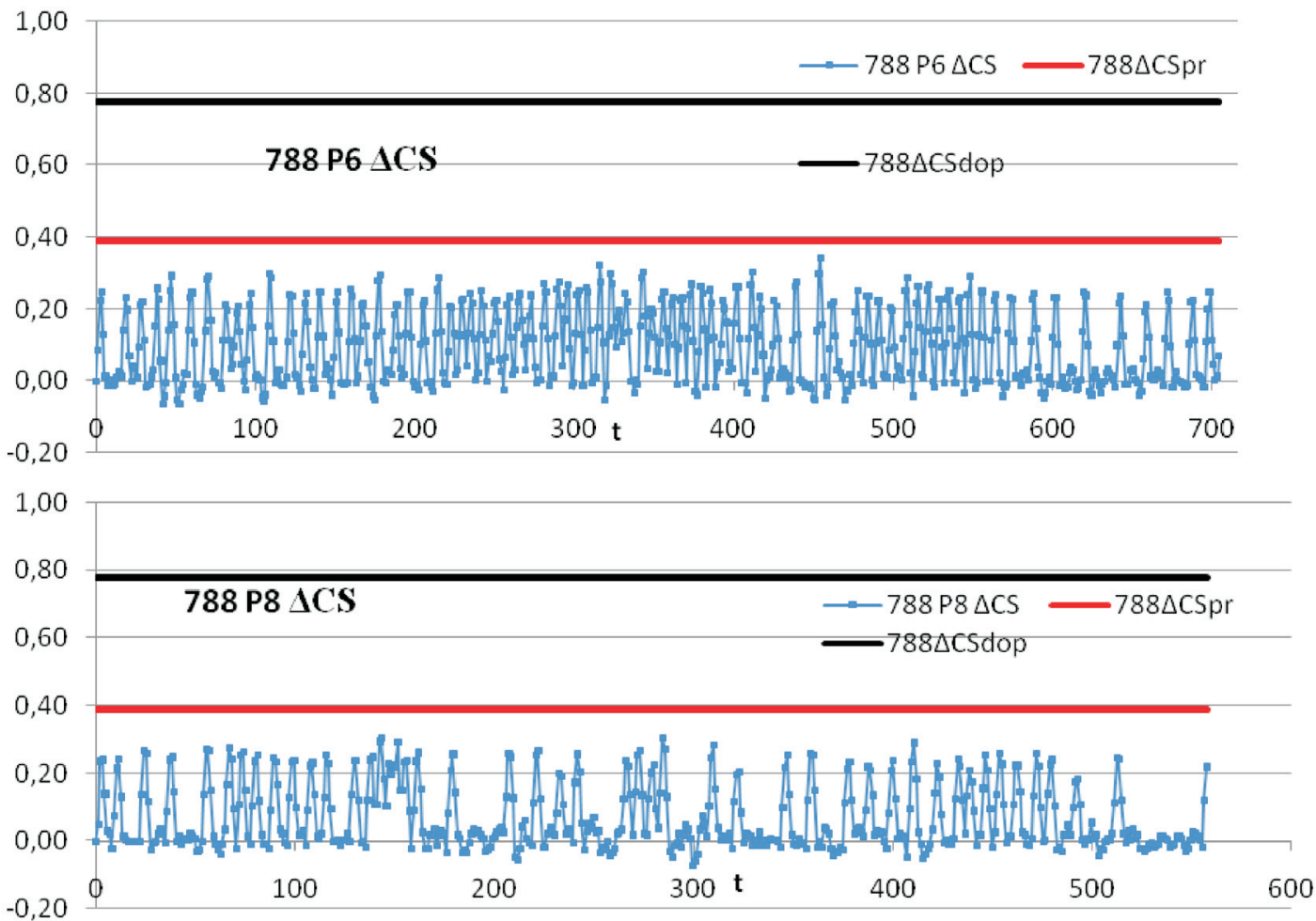

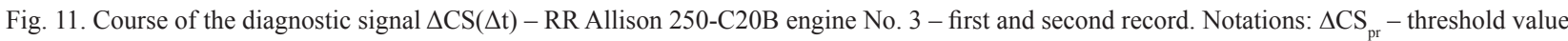
of the diagnostic signal, $\Delta \mathrm{CS}_{\mathrm{dop}}-$ maximum admissible value of the diagnostic signal

Rys. 11. Przebieg funkcjonalnego sygnatu diagnostycznego $\triangle C S(\Delta t)$ - silnik RR Allison 250-C20B nr 3-pierwsza i druga rejestracja. Oznaczenia: $\Delta C S_{p r}$ - wartość progowa sygnatu diagnostycznego, $\Delta C S_{\text {dop }}$ - wartość dopuszczalna sygnału diagnostycznego 


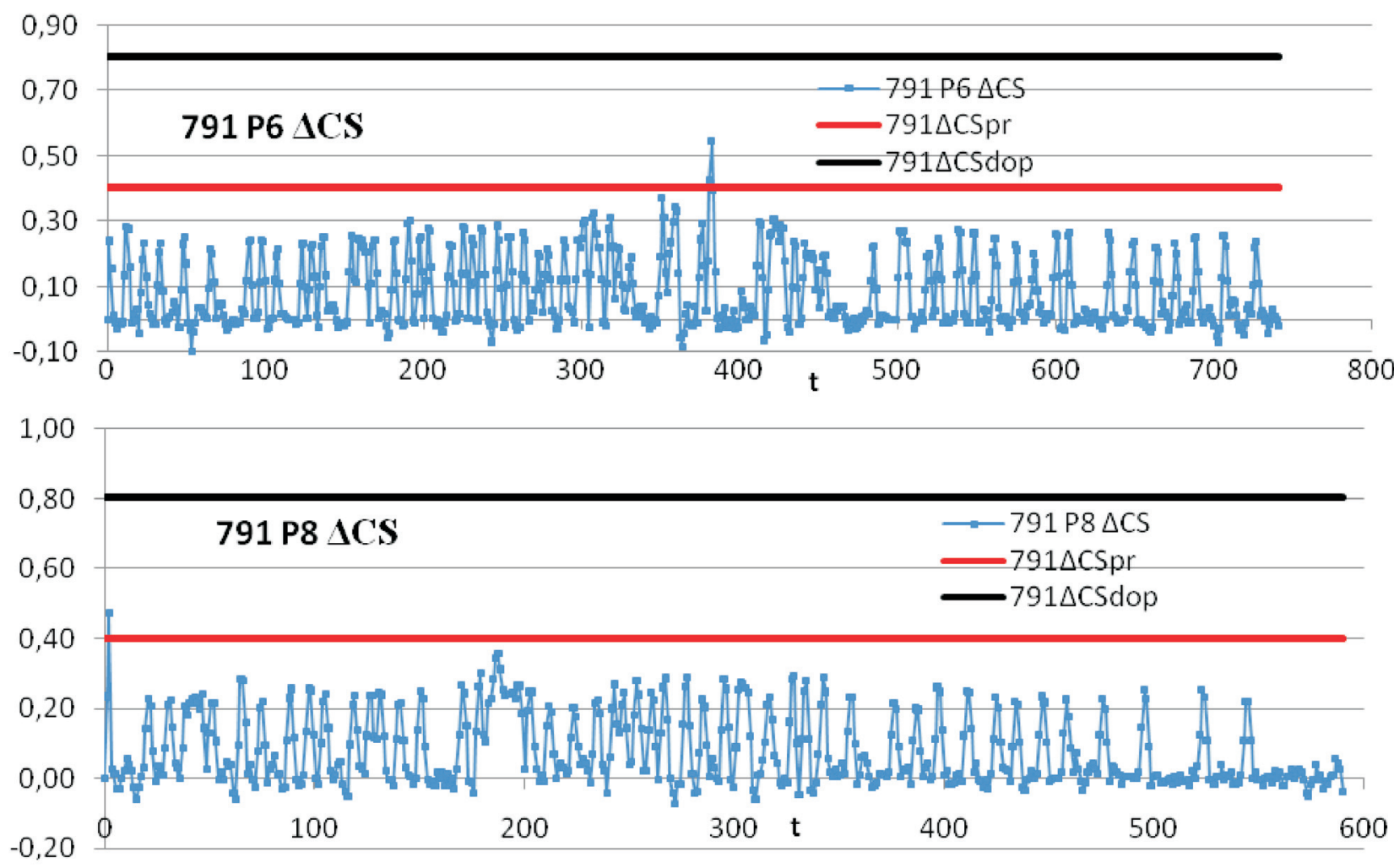

Fig. 12. Course of the diagnostic signal $\Delta \mathrm{CS}(\Delta \mathrm{t})-\mathrm{RR}$ Allison 250-C20B engine No. $4-$ first and second record. Notations: $\Delta C \mathrm{C}_{\mathrm{pr}}-$ threshold value of the diagnostic signal, $\triangle \mathrm{CS}_{\mathrm{dop}}-$ maximum admissible value of the diagnostic signal

Rys. 12. Przebieg funkcjonalnego sygnału diagnostycznego $\triangle C S(\Delta t)$ - silnik RR Allison 250-C20B nr 4 - pierwsza i druga rejestracja. Oznaczenia: $\triangle C S_{p r}$ - wartość progowa sygnału diagnostycznego, $\Delta C S_{\text {dop }}$ - wartość dopuszczalna sygnału diagnostycznego

was impossible in such a short period of time of their operation after only two recordings for each unit. Hence, the above assumption of the actual oil consumption does not influence the conclusions resulting from the investigations.

Figures 9-12 show the courses of the functional diagnostic signals $\Delta \mathrm{CS}(\Delta \mathrm{t})$ recorded for the Rolls-Royce Allison 250-C20B helicopter turbine engines.

\subsection{Excess of the threshold value of the functional diagnostic signal}

If, in certain measurement interval $\Delta \mathrm{t}$ the value of the increment of PM content $\Delta \mathrm{CS}(\Delta \mathrm{t})$ exceeds threshold value $\Delta \mathrm{CSpr}$, then the excess of the threshold value takes place in this interval:

$$
\mathrm{p}(\Delta \mathrm{t})=\Delta \mathrm{CS}(\Delta \mathrm{t})-\Delta \mathrm{CS}_{\mathrm{pr}}
$$

Functional diagnostic signal $\Delta \mathrm{CS}(\Delta \mathrm{t})$ throughout the whole period of operation cannot exceed maximum admissible value $\Delta \mathrm{CS}_{\mathrm{dop}}$. This limitation determines the maximum admissible excess of the threshold value:

$$
\mathrm{p}_{\mathrm{dop}}=\Delta \mathrm{CS}_{\mathrm{dop}}-\Delta \mathrm{CS}_{\mathrm{pr}}
$$

Figure 13 shows the above-discussed excess.

The excess of the threshold value is a positive value expressed in units appropriate for the physical quantity representing the diagnostic signal. If the signal value does not exceed the threshold value we assume that the excess value is zero.

\subsection{Przekroczenie wartości progowej funkcjonalnego sygnału diagnostycznego}

Jeżeli w pewnym okresie pomiarowym $\Delta$ t wartość przyrostu zawartości cząstek stałych $\Delta \mathrm{CS}(\Delta \mathrm{t})$ będzie większa niż wartość progowa $\Delta \mathrm{CS}_{\mathrm{pr}}$, to w tym okresie pojawiło się przekroczenie wartości progowej (5).

Funkcjonalny sygnał diagnostyczny $\Delta \mathrm{CS}(\Delta \mathrm{t}) \mathrm{w}$ ciągu całego okresu eksploatacji silnika nie może przekroczyć wartości dopuszczalnej $\Delta \mathrm{CS}_{\text {dop }}$. Ograniczenie to wyznacza maksymalną dopuszczalną wartość przekroczenia wartości progowej (6).

Na rysunku 13 przedstawiono omówione powyżej przekroczenia.

Przekroczenie wartości progowej jest liczbą dodatnią, wyrażoną w jednostkach właściwych dla reprezentującej sygnał diagnostyczny wielkości fizycznej. Jeżeli wartość sygnału nie przekracza wartości progowej, przyjmuje się, że wartość przekroczenia wynosi zero.

\subsection{Wskaźnik stanu technicznego}

Z każdym przekroczeniem wartości progowej $\mathrm{p}(\Delta \mathrm{t})$ związana jest generująca je zmiana wartości funkcjonalnego sygnału diagnostycznego, której przyczyną jest z kolei zmiana (degradacja) stanu technicznego obiektu, wpływająca na jego funkcjonowanie. Stan techniczny uszczelnień łożysk określony na podstawie zawartości cząstek stałych w gazach wylotowych przedstawia wskaźnik (7).

Jeżeli sygnał $\Delta \mathrm{CS}(\Delta \mathrm{t})$ nie przekracza wartości progowej $(\mathrm{p}(\Delta \mathrm{t})=0)$, to wskaźnik stanu $\mathrm{S}_{\mathrm{CS}}(\Delta \mathrm{t})=1$. Jeżeli pojawią 


\subsection{Technical condition index}

With each excess of the threshold value $\mathrm{p}(\Delta \mathrm{t})$ there is a change in the value of the functional diagnostic signal that generates this threshold, whose cause is the change (deterioration) of the technical condition of the object that influences its operation. The technical condition of the bearing seals determined based on the PM content in the exhaust gases is presented by the following index:

$$
\mathrm{S}_{\mathrm{CS}}(\Delta \mathrm{t})=1-\frac{\mathrm{p}(\Delta \mathrm{t})}{\mathrm{p}_{\mathrm{dop}}}
$$

If signal $\Delta \mathrm{CS}(\Delta \mathrm{t})$ does not exceed the threshold value $(\mathrm{p}(\Delta \mathrm{t})=0)$ then technical condition index $\mathrm{S}_{\mathrm{CS}}(\Delta \mathrm{t})=1$. If there are excess values lower than the maximum admissible one the index will assume the values in the range $(0,1)$. If an maximum admissible excess occurs the index will be zero, which denotes that the engine has to be withdrawn from operation until the cause is eliminated.

Within a single recording we can obtain a set of values of the technical condition indexes in the time domain $t$ (short term), corresponding to the individual excesses of the threshold value.

The technical condition index for the whole recording in the operation time domain $\Theta$ (long term) is determined by the relation:

$$
S_{C S}(\theta)=\sqrt[k]{\prod_{i=1}^{k} S_{C S i}(\Delta t)}
$$

where: $\mathrm{k}$ - number of measurement intervals $\Delta \mathrm{t}$, where the excess of the threshold value took place during the recording of the $\Delta \mathrm{CS}(\Delta t)$ signal after $\Theta$ of the engine operation.

The values of the technical condition indexes $\mathrm{S}_{\mathrm{CS}}(\Theta)$ for the individual recordings carried out for four tested Rolls-Royce Allison 250 C20B engines have been shown in Table 2.

Table 2. Technical condition index $\mathrm{S}_{\mathrm{CS}}(\Theta)$ determined based on the threshold excess values of the functional diagnostic signal $\Delta \operatorname{CS}(\Delta t)$ for RR Allison 250-C20B engines

Tabela 2. Wskaźnik stanu technicznego $S_{C S}(\Theta)$ wyznaczony na podstawie przekroczeń wartości progowych funkcjonalnego sygnału diagnostycznego $\triangle C S(\Delta t)$ dla silników RR Allison 250-C20B

\begin{tabular}{|c|c|c|c|c|}
\hline \multirow{2}{*}{} & \multicolumn{4}{|c|}{ Engine No. } \\
\cline { 2 - 5 } & 1 & 2 & 3 & 4 \\
\hline Time $[\Theta]$ & \multicolumn{4}{|c|}{ Technical state index $\mathrm{S}_{\mathrm{CS}}(\Theta)$} \\
\hline 2522 & 0.9402 & 1.0000 & & \\
\hline 2545 & 0.8736 & 0.9306 & & \\
\hline 2790 & & & 1.0000 & 0.8936 \\
\hline 2806 & & & 1.0000 & 1.0000 \\
\hline
\end{tabular}

\section{Conclusions}

In the paper a method of identification of the technical condition index of an object (in this case - the bearing seals of the turbine engine shafts) has been presented based on the technical conditions index defined by the authors.

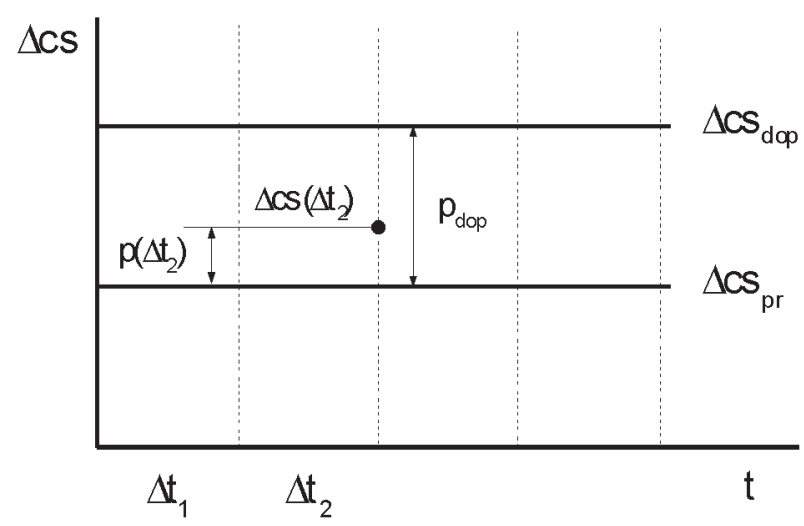

Fig. 13. Excess of the threshold value of the functional diagnostic signal and the maximum admissible excess of the functional diagnostic signal. Notations: $\Delta \mathrm{CS}$ - functional diagnostic signal, $\Delta \mathrm{t}$ - measuring interval, $\Delta \mathrm{CS}_{\mathrm{pr}}$ - threshold value of the diagnostic signal, $\Delta \mathrm{CS}_{\mathrm{dop}}-$ maximum admissible value of the diagnostic signal, $\mathrm{p}(\Delta \mathrm{t})$ - excess of the threshold diagnostic signal value, $p_{\text {dop }}$ - maximum admissible excess of the functional diagnostic signal

Rys. 13. Przekroczenie wartości progowej funkcjonalnego sygnału diagnostycznego i przekroczenie dopuszczalne funkcjonalnego sygnału diagnostycznego. Oznaczenia: $\triangle C S$ - funkcjonalny sygnal diagnostycz$n y, \Delta t$-okres pomiarowy, $\Delta C S_{p r}$ - wartość progowa sygnatu diagnostycznego, $\triangle C S_{\text {dop }}$ - wartość dopuszczalna sygnału diagnostycznego, $p(\Delta t)$ - przekroczenie wartości progowej sygnału diagnostycznego, $p_{d o p}$

- przekroczenie dopuszczalne wartości sygnału diagnostycznego

się przekroczenia mniejsze od dopuszczalnego, wskaźnik będzie przyjmował wartości z przedziału $(0,1)$. W przypadku pojawienia się przekroczenia dopuszczalnego wskaźnik przyjmie wartość zero, co oznacza konieczność przerwania użytkowania silnika do czasu usunięcia przyczyny, która to przekroczenie wywołała.

W ramach jednej rejestracji można otrzymać zbiór wartości wskaźników stanu w dziedzinie czasu krótkiego t, odpowiadających poszczególnym przekroczeniom wartości progowej.

Wskaźnik stanu technicznego dla całej rejestracji w dziedzinie czasu eksploatacji $\Theta$ (długiego) określa zależność (8), gdzie: $\mathrm{k}$ - liczba okresów pomiarowych $\Delta \mathrm{t}$, w których pojawiło się przekroczenie wartości progowej w czasie rejestracji sygnału $\Delta \operatorname{CS}(\Delta t)$ po czasie $\Theta$ użytkowania silnika.

Wartości wskaźników stanu technicznego $\mathrm{S}_{\mathrm{CS}}(\Theta)$ dla poszczególnych rejestracji wykonanych dla czterech badanych silników Rolls-Royce Allison 250 C20B przedstawiono w tabeli 2.

\section{Podsumowanie}

W opracowaniu przedstawiono metodę identyfikowania stanu technicznego obiektu (w tym przypadku uszczelnień łożysk wałów wirnika silnika turbinowego) za pomocą zdefiniowanego przez autorów wskaźnika stanu.

Wskaźnik stanu technicznego wyznaczony w dziedzinie czasu krótkiego t charakteryzuje się następującymi właściwościami:

a) jest liczbą bezwymiarowa,

b) przyjmuje wartości z przedziału $(0 \div 1)$,

c) przyjmuje wartość 1 , jeżeli związany z nim funkcjonalny sygnał diagnostyczny nie przekracza wartości progowej, 
The technical condition index determined in the time domain $\mathrm{t}$ (short term) is characterized by the following properties:

a) it is a dimensionless number,

b) assumes values from $0 \div 1$,

c) assumes 1, if the relevant functional diagnostic signal does not exceed the threshold value,

d) assumes values less than 1 if there are excesses of the threshold value lower than the maximum admissible excess,

e) assumes the value of 0 if the excess of the threshold value reaches the maximum admissible value.

The technical condition index assumes the value of 1 if all the indexes equal 1 . The technical condition index is determined in the operation time domain $\Theta$ based on the value of the indexes determined in the short term time domain $t$, being the domain of function $\Delta \mathrm{CS}(\Delta \mathrm{t})$ determined as a result of each signal recording.

The technical condition index assumes the value lower than 1 if at least one of the indexes determined in short term time domain $t$ is lower than 1 and assumes the value of 0 , if at least one of them assumes that value.

Analyzing the indexes of the $\mathrm{S}_{\mathrm{CS}}(\Theta)$ presented in Table 1 we can observe that in relation to engine 1 there occurred excesses of threshold value $\Delta \mathrm{CS}(\Delta \mathrm{t})$ that led to the reduction of the technical condition indexes determined for both recordings. A confirmation of this result may be the appearance of smoke from the exhaust pipes after the engine stop. The result seems particularly valuable since it was obtained with a relatively low number of measurements (trials) and the conclusions are in line with the observations made earlier during regular operation of the tested engines.

Taking the above into account we state that the presented technical conditions index determined based on the measurements of the PM content in the exhaust gases is a reliable tool for the identification of the technical conditions of a turbine combustion engine. d) przyjmuje wartości mniejsze od 1 , jeżeli pojawią się przekroczenia wartości progowej mniejsze od przekroczenia dopuszczalnego,

e) przyjmuje wartość 0 , jeżeli przekroczenie wartości progowej osiągnie wartość dopuszczalną.

Wskaźnik stanu technicznego wyznaczony w dziedzinie czasu eksploatacji $\Theta$ na podstawie wartości wskaźników wyznaczonych w dziedzinie czasu krótkiego t (dziedzina funkcji $\Delta \mathrm{CS}(\Delta \mathrm{t})$ wyznaczanej w wyniku każdej rejestracji sygnału) przyjmie wartość 1, jeżeli wszystkie te wskaźniki będą równe 1 .

Wskaźnik stanu technicznego przyjmie wartość mniejszą od 1, jeżeli chociaż jeden ze wskaźników wyznaczonych w dziedzinie czasu krótkiego t będzie mniejszy od 1 oraz przyjmie wartość 0 , jeżeli co najmniej jeden z nich przyjmie tę wartość.

Analizując wartości wskaźników $\mathrm{S}_{\mathrm{CS}}(\Theta)$ przedstawione w tabeli 1, można zauważyć, że w odniesieniu do silnika nr 1 wystąpiły przekroczenia wartości progowej sygnału $\Delta \mathrm{CS}(\Delta \mathrm{t})$ powodujące zmniejszenie wartości wskaźników stanu wyznaczonych dla obydwu rejestracji. Potwierdzeniem tego wyniku jest pojawienie się dymienia $\mathrm{z}$ rur wylotowych po wyłączeniu silnika po pierwszej rejestracji. Wynik wydaje się tym cenniejszy, że otrzymano go przy stosunkowo niewielkiej liczbie pomiarów (prób), a wnioski pokrywają się z obserwacjami dokonanymi już wcześniej podczas normalnej eksploatacji badanych silników.

Uwzględniając powyższe, należy sądzić, że przedstawiony wskaźnik stanu technicznego, określony na podstawie pomiarów zawartości cząstek stałych w gazach wylotowych, może być wiarygodnym narzędziem identyfikacji stanu technicznego turbinowego silnika spalinowego.

Paper reviewed/Artykut recenzowany

\section{Bibliography/Literatura}

[1] Pawlik T.: Engine Training Manual for Model 250 C-20B, Allison Turbine Division of General Motors Corporation 1989, tłum. polskie, Świdnik 2009.

[2] Golomb P.: New Method for Particulate Matter Measurement with TEOM Diesel Particulate Mass Monitor, PTNSS Congress, Cracow 2007.

[3] Magier J.: The estimation of technical state of helicopter turbine engine bearing system, PTNSS Congress, Cracow 2007.

Jerzy Dutczak, DEng. - doctor in the Department of Combustion Engines, Faculty of Mechanics at Cracow University of Technology.

Dr inż. Jerzy Dutczak - adiunkt w Katedrze Silników Spalinowych na Wydziale Mechanicznym Politechniki Krakowskiej.

e-mail:jdutczak@usk.pk.edu.pl

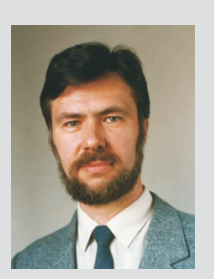

[4] Dutczak J.: Application Of The TEOM Analyser To SI Engine Particulates Emissions Measurement, International Congress Motor Vehicles \& Motors 2008, Kragujevac 2008.

[5] Dutczak J., Magier J.: Conception of evaluation of technical state of turbine engine elements on the base of exhaust gases chemical composition changes, Combustion Engines/Silniki Spalinowe nr 2009-SC1, PTNSS June 2009.

[6] Dutczak J.: Investigation of the particle matter emission in the exhaust gas of the GTD-350 turbine engine, PTNSS-2011-SC173, Combustion Engines/Silniki Spalinowe nr 3/2011.

Janusz Magier, DEng. - Polish Aviation. Dr inż. Janusz Magier - pracownik lotnictwa państwowego.

e-mail: janusz.magier@gmail.com 